\title{
Cadmium distribution in gonads of the sea urchin Strongylocentrotus intermedius
}

\author{
I. G. Lipina ${ }^{1}$, S. M. Gnezdilova ${ }^{1}$ \& N. K. Khristoforova ${ }^{2}$ \\ ${ }^{1}$ Institute of Marine Biology and ${ }^{2}$ Pacific Institute of Geography, Far East Science Center, Academy of Sciences of the USSR, \\ Vladivostok 690022, USSR
}

\begin{abstract}
The histochemical reaction of silver sulfide was used to reveal $\mathrm{Cd}$ appearance in the gonad of the sea urchin after different $\mathrm{Cd}$ exposure intervals. Over $40 \mathrm{~d}$ exposure the pattern of $\mathrm{Cd}$ appearance had the following sequence: coelome $\rightarrow$ gonad wall $\rightarrow$ intercellular spaces $\rightarrow$ accessory cells $\rightarrow$ gametes.
\end{abstract}

\section{INTRODUCTION}

Cadmium is known for its organospecific effect upon the reproductive system in higher animals (Levina 1972, Nozdryukhina 1977).

In a previous study on chronic cadmium impacts on gametogenesis, we examined histochemical changes in gonads of mature sea urchins Strongylocentrotus intermedius, a species which is widely used in toxicological and pharmacological tests (Khristoforova et al. 1984). In sea urchins subjected to high cadmium concentrations ( 1.0 and $\left.0.5 \mathrm{mg} \mathrm{Cd}^{-1}\right)$, a majority of oocytes and ripe egg cells degenerated before other signs of distress were evident. At $0.5 \mathrm{mg} \mathrm{Cdl}^{-1}$, degenerative changes in gametes were accompanied by stimulation of oogonium formation. After exposure to $0.1 \mathrm{mg} \mathrm{Cd} \mathrm{l}^{-1}$ for $40 \mathrm{~d}$, no effects on behaviour or histological structure of growing oocytes were observed. However, the number of oogonia was 1.5 times greater than controls, but all these embryos developed abnormally.

An electron-microscopic study has shown that exposure to $0.1 \mathrm{mg} \mathrm{Cd} \mathrm{l}^{-1}$ resulted in destruction of oocytes and gonad accessory cells (Gnezdilova et al. 1985).

This paper explores uptake of cadmium by sea urchin gonads and distribution and translocation of cadmium during exposure.

\section{MATERIALS AND METHODS}

Experiments were conducted in April-May 1983 at the 'Vityaz' marine research station of the Far East Science Center (USSR Acad. Sci.) and at the 'Stark' marine biological station of the Institute of Marine Biology, both stations being located on the Sea of Japan. .

We used 80 mature sea urchins Strongylocentrotus intermedius, 50 to $60 \mathrm{~mm}$ in diameter, with gonads in the active stage of gametogenesis. Control and test specimens were kept in 3 closed aquaria, $100 \mathrm{l}$ each, with aerated seawater. Controls (40 individuals) were kept in Cd-free seawater. Sea urchins were fed on the seaweeds Ulva and Laminaria. We conducted 2 experiments: (1) 20 sea urchins were exposed for $15 \mathrm{~d}$ to $1 \mathrm{mg}$ $\mathrm{Cd} \mathrm{l}^{-1}$, and (2) 20 sea urchins were held for $40 \mathrm{~d}$ at $0.08 \mathrm{mg} \mathrm{Cdl^{-1 }}$. Gonads were extracted from sea urchins and fixed on Days 6 and 15 in the first experiment and on Day 40 in the second experiment in ethanol-acetic acid mixture $(3: 1)$ and embedded in paraffin. Sections were cut $5 \mu \mathrm{m}$ thick and stained in Caracci hematoxylin and $1 \%$ eosin.

Localization of $\mathrm{Cd}$ in the gonad was determined by the sulfide-silver method in ultrathin sections. Gonad pieces were fixed for $2 \mathrm{~h}$ in $2.5 \%$ glutaraldehyde with a phosphate buffer saturated with hydrogen sulfide, washed for $2 \mathrm{~d}$ in phosphate buffer ( $\mathrm{pH} 7.8)$, treated with a mixture of gum, silver nitrate, citric acid and hydroquinone in the ratio given by Timm (1958), postfixed for $1 \mathrm{~h}$ in $1 \% \mathrm{OsO}_{4}$, dehydrated, and embedded in Epon. Ultrathin sections stained with uranyl acetate and lead citrate were analyzed and photographed on an electron microscope.

\section{RESULTS}

Localization of $\mathrm{Cd}$ in gonads was revealed by precipitation tests. Single grains of Cd sulfide detected in 
gonads of male and female control specimens did not show any specific pattern of distribution.

After exposure for $6 \mathrm{~d}$ to $1 \mathrm{mg} \mathrm{Cd} \mathrm{l}^{-1}$, gonads of male and female individuals showed similar patterns of $\mathrm{Cd}$ localization. The precipitate was first revealed on the gonad wall (Fig. 1a) and in intercellular spaces (Fig. 1b). A few grains were found in globules of accessory cells (Fig. 1c). Gametes of male specimens did not include the precipitate, and in female gonads the precipitate was seen on the surface of the plasma mem- brane of oocytes (Fig. 1d). After exposure for $15 \mathrm{~d}, \mathrm{Cd}$ containing precipitate appeared in male sea urchins mostly in spermatogonia, spermatocytes and spermatids (Fig. 2a, b) and increased in females in oogonia and small oocyets (Fig. 2c). In males and females, some grains were included in gamete nuclei. The precipitate was more abundant in accessory cells than in gametes and was detected in globules, in the zone of endoplasmic retıculum, in mitochondria, cytoplasma matrix and in nuclei. The number of grains in globules varied from
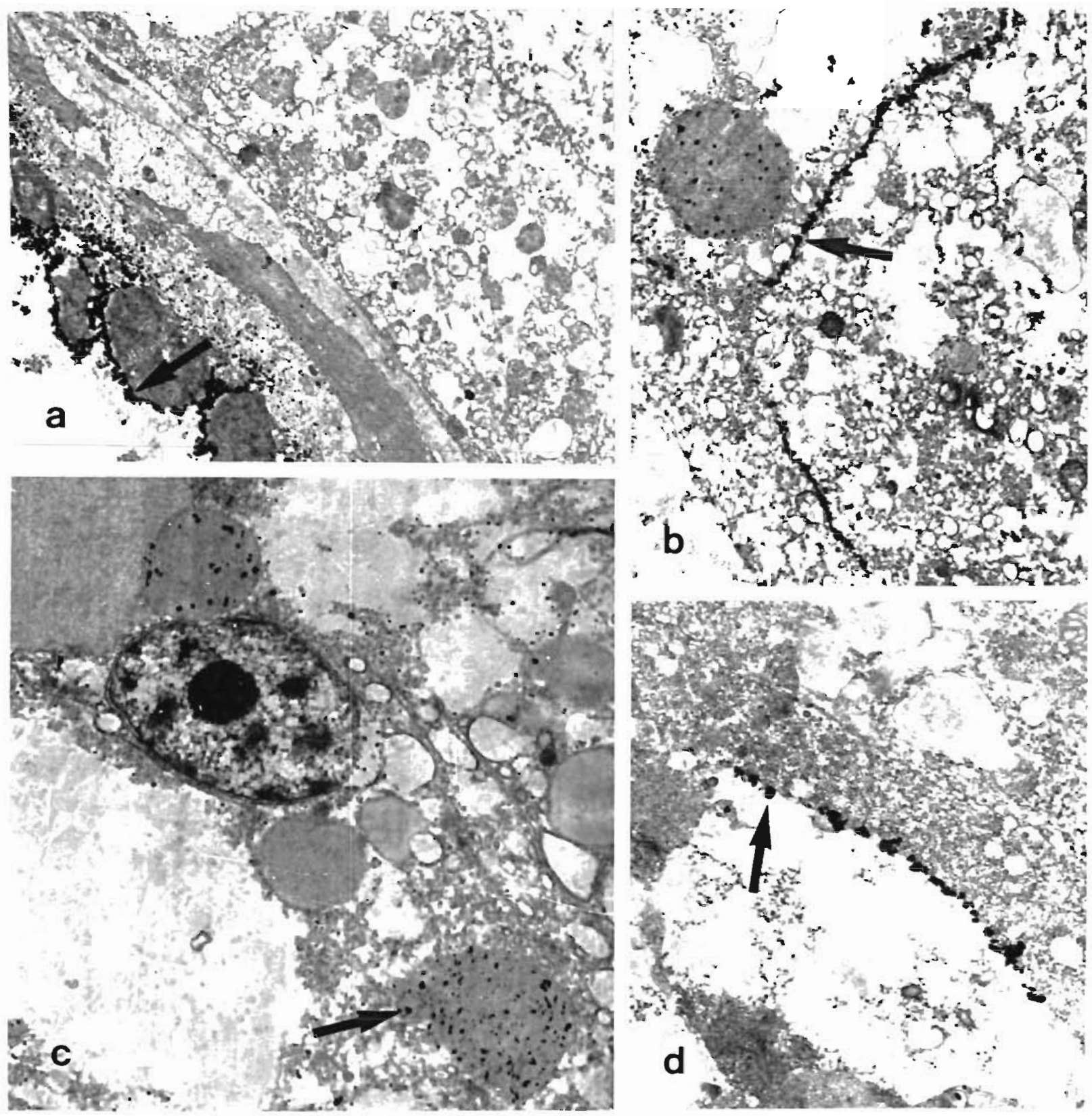

Fig. 1. Strongylocentrotus intermedius Electronograms showing distribution of Cd-containing precipitates in gonads of sea urchins after $6 \mathrm{~d}$ exposure to $\mathrm{Cd}, 1 \mathrm{mg} \mathrm{l}^{-1}$ Arrows indicate precipitates. (a) Gonad wall. $6000 \times$. (b) Intercellular spaces. $10000 \times$. (c) Gonad accessory cells $15000 \times$. (d) Ovocytes; the precipitate 15 seen on the plasma membrane. $15000 \times$ 

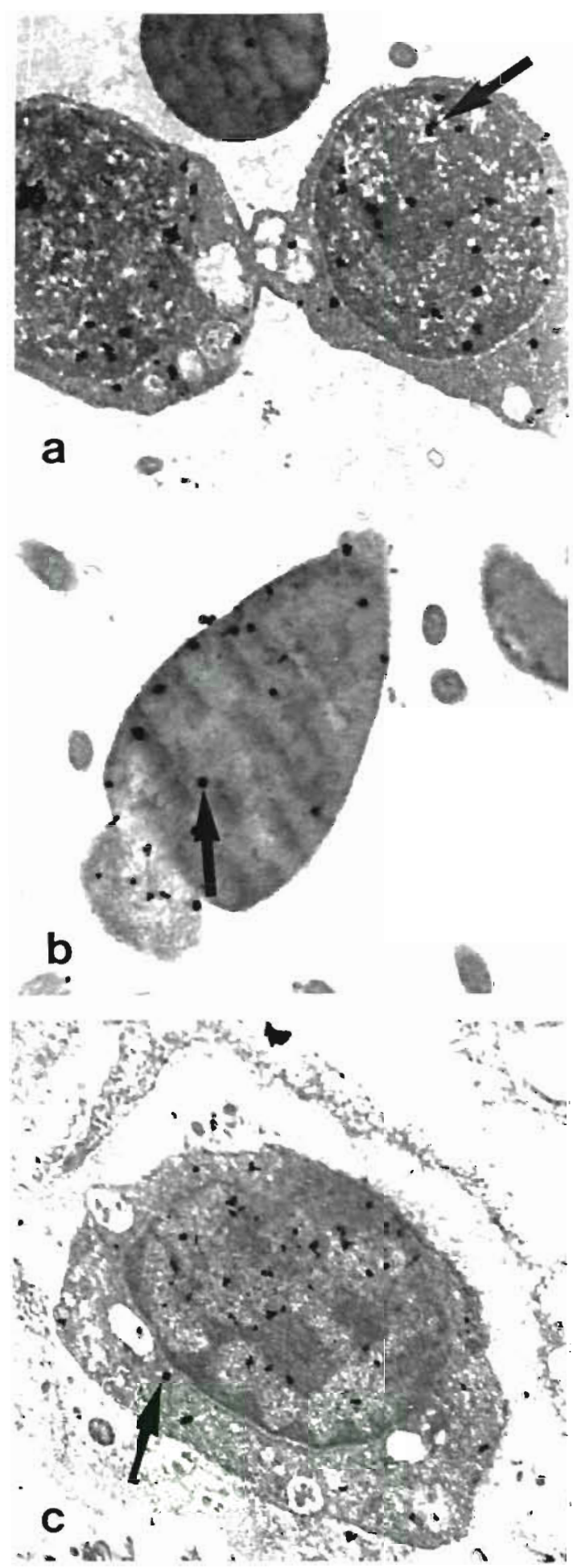

Fig. 2. Strongylocentrotus intermedius. Electronograms showing distribution of Cd-containing precipitates in gonads of sea urchins after $15 \mathrm{~d}$ exposure to $\mathrm{Cd}, 1 \mathrm{mg} \mathrm{l}^{-1}$. Arrows indicate precipitates. (a) Spermatocytes. $40000 \times$. (b) A spermatid. $40000 x$. (c) An oocyte. $6000 \times$ about 10 to 100 and sometimes more. After $40 \mathrm{~d}$ exposure to $0.08 \mathrm{mg} \mathrm{Cd}^{-1}$, the precipitate was found in gametes and in accessory cells.

Thus, localization of the precipitate depended on the duration of exposure. Cd first appeared in gonad walls and accessory cells, then in gametes.

\section{DISCUSSION}

In the present experiments, the precipitate showing Cd distribution in Strongylocentrotus intermedius gonads was found in gametes and in accessory cells. Cadmium incorporation by gametes, and by their nuclei in particular, seems to be responsible for the low quality of reproductive products which results in a high percentage of abnormal offspring (Khristoforova et al. 1984). As gonad accessory cells contained a major portion of the precipitate, we suggest that the accessory cells have a protective function against toxic impacts.

Detoxification of heavy metals in tissues of marine invertebrates is realized (1) by binding with metallothioneins and metallothionein-like proteins (Noël-Lambot et al. 1980) and (2) by incorporation into intracellular granules (Simkiss 1976, Coombs \& George 1978). The granules are able to regulate the content of metal ions and eliminate potentially toxic agents in the intracellular medium through mineralization (Simkiss 1976). Thus detoxification of $\mathrm{Cd}$ may be achieved by metal-binding proteins (metallothioneins) as in oysters (Ridlington \& Fowler 1979), mussels (George \& Pirie 1979, George et al. 1979) and the sea limpet Patella vulgata (Noël-Lambot et al. 1980), or by metallic granules and kidney concretions, as in the scallop Argopecten irradians (Carmichael \& Fowler 1981).

In accessory cells of sea urchin gonads, the precipitate was found in globules, nuclei, in the zone of endoplasmic reticulum, in mitochondria and in the cytoplasmic matrix. Granules and concretions were not found. Probably, cadmium is inactivated through binding by organic ligands. Jenkins et al. (1982) found that sea urchins Strongylocentrotus purpuratus from contaminated environments produced metal-binding proteins in response to increased contents of $\mathrm{Zn}, \mathrm{Cu}$ and Cd. Simkiss \& Taylor (1981) studied the distribution of radioisotopes in the hepatopancreas of the snail Helix aspera and found that metals are accumulated in 2 different ways. $\mathrm{Cd}, \mathrm{Cu}, \mathrm{Zn}$ and $\mathrm{Hg}$ intrude through the cellular plasma membrane and are bound in the cytoplasm with metallothionein-like proteins, while $\mathrm{Mn}$, $\mathrm{Fe}$ and $\mathrm{Pb}$ are incorporated into phosphatic granules. Proteins capable of binding $\mathrm{Cd}$ are very stable and localize in Mytilus edulis in lysosomes (George \& Pirie 
$1979,1980)$. It is therefore possible that final granules are really a conglomeration of several different systems including ligands (Simkiss et al. 1982).

Our experiments have shown that exposure of sea urchins to $\mathrm{Cd}$ for $40 \mathrm{~d}$ resulted in appearance of $\mathrm{Cd}$ in the gonad. It is likely that $\mathrm{Cd}$ is bound with organic ligands although we did not find any granules or vesicles. Uptake and distribution of $\mathrm{Cd}$ had the following sequence: coelome $\rightarrow$ gonad wall $\rightarrow$ intercellular spaces $\rightarrow$ accessory cells $\rightarrow$ gametes. Gametes may include $\mathrm{Cd}$ directly from intercellular spaces.

Acknowledgements. The author thank Professor A. V. Zhirmunsky for critical reading of the manuscript.

\section{LITERATURE CITED}

Carmichael, N. G., Fowler, B. A. (1981). Cadmiun accumulation and toxicity in the kidney of the bay scallop Argopecten irradians. Mar. Biol. 65: 35-43

Coombs, T. L., George, S. G. (1978). Mechanisms of immobili. zation and detoxication of metals in marine organisms. In: McLusky, D. S., Berry, A. J. (ed.) Physiology and behaviour of marine organisms. Proceedings of the 12th European Symposium on Marine Biology. Pergamon Press, Oxford, p. 179-187

George, S. G., Carpene, E., Coombs, T. L., Overnell, J., Youngson, A. (1979). Characterization of Cd-binding proteins from mussels, Mytilus edulis, exposed to $\mathrm{Cd}$. Biochim. Biophys. Acta 580 (2): 225-233

George, S. G., Pirie, B. J. (1979). The occurrence of cadmium in subcellular particles in the kidney of the marine mussel, Mytilus edulis, exposed to cadmium. The results of electron microscope analysis. Biochim. Biophys. Acta 580 (2): 234 244

George, S. G., Pirie, B. J. (1980). Metabolism of zinc in the mussel Mytilus edulis: a combined ultrastructural and biochemical study. J. mar. biol. Ass. U.K. 60: 575-590

Gnezdilova, S. M., Khristoforova, N. K., Lipina, I. G. (1985). Gonadotoxic and embryotoxic effect of cadmium in sea urchins. Symposia Biological Hungarica 29: 239-251

Jenkins, K. D., Brown, D. A., Oshida, P. S., Perkins, E. M. (1982). Cytosolic metal distribution as an indicator of toxicity in sea urchins from the Southern California Bight. Mar. Pollut. Bull. 131: 413-421

Khristoforova, N. K., Gnezdilova, S. M., Vlasova, G. A. (1984). Effects of cadmium on gametogenesis and offspring of the sea urchin, Strongylocentrotus intermedius. Mar. Ecol. Prog. Ser. 17: 9-14

Levina, E. N. (1972). General toxicology of metals. Medicine, Leningrad. (Russian)

Noël-Lambot, F., Bouquegneau, J. M., Frankenne, F., Disteche, A. (1980). Cadmium, zinc and copper accumulation in limpets (Paetella vulgata) from the Bristol Channel with special reference to metallothioneins. Mar. Ecol. Prog. Ser. 2: 81-89

Nozdryukhina, L. R. (1977). Biological role of trace elements in animal and man. Nauka, Moscow. (Russian)

Ridlington, J. W., Fowler, B. A. (1979). Isolation and partial characterization of a Cd-binding protein from American oyster (Crassostrea virginica). Chemico-Biol. Interactions 25: $127-138$

Simkiss, K. (1976). Intracellular and extracellular routes in bio-mineralization. Symp. Soc. exp. Biol. 30: 423-444

Simkiss, K., Taylor, M. (1981). Cellular mechanisms of metal ion detoxication and some new indices of pollution. Aquat. Toxicol. 1: 279-290

Simkiss, K., Taylor, M., Mason, A. Z. (1982). Metal detoxication and bioaccumulation in molluscs. Mar. Biol. Lett. 3: $187-201$

Timm, F. (1958). Zur Histochemie der Schwermetalle: das Sulfidsilberverfahren. Dtsch. Z. gerichtl. Med. 46: 706-711 